\title{
A Comparison of the Dinosaur Communities from the Middle Jurassic of the Cleveland (Yorkshire) and Hebrides (Skye) Basins, Based on Their Ichnites
}

\author{
Mike Romano ${ }^{1, *}$, Neil D. L. Clark ${ }^{2}$ (1) and Stephen L. Brusatte ${ }^{3}$ \\ 1 Independent Researcher, 14 Green Lane, Dronfield, Sheffield S18 2LZ, UK \\ 2 Curator of Palaeontology, The Hunterian, University of Glasgow, University Avenue, Glasgow G12 8QQ, \\ UK; neil.clark@glasgow.ac.uk \\ 3 Chancellor's Fellow in Vertebrate Palaeontology, Grant Institute, School of Geosciences, \\ University of Edinburgh, The King's Buildings, James Hutton Road, Edinburgh EH9 3FE, UK; \\ Stephen.Brusatte@ed.ac.uk \\ * Correspondence: m.romano@sheffield.ac.uk; Tel.: +44-01246-417330
}

Received: 30 July 2018; Accepted: 25 August 2018; Published: 31 August 2018

\begin{abstract}
Despite the Hebrides and Cleveland basins being geographically close, research has not previously been carried out to determine faunal similarities and assess the possibility of links between the dinosaur populations. The palaeogeography of both areas during the Middle Jurassic shows that there were no elevated landmasses being eroded to produce conglomeratic material in the basins at that time. The low-lying landscape and connected shorelines may have provided connectivity between the two dinosaur populations. The dinosaur fauna of the Hebrides and Cleveland basins has been assessed based primarily on the abundant ichnites found in both areas as well as their skeletal remains. In the two basins, the dinosaur faunas are very similar, consisting of non-neosauropod eusauropods, a possible basal titanosauriform, large and small theropods and ornithopods and europodan thyreophorans. The main difference in the faunas is in the sizes. In the Cleveland Basin, the ichnites suggest that there were medium and large theropods alongside small to medium sized ornithopods, whereas, in the Hebrides Basin, the theropods were from small to large and the ornithopods were medium to large. It is suggested that migrations could have taken place between the two areas during the Middle Jurassic. A tentative food chain from the herbivorous dinosaurs to the top predators can be inferred from the footprints.
\end{abstract}

Keywords: ichnite; Skye; Yorkshire; footprints; dinosaur; sauropod; theropod; ornithopod

\section{Introduction}

The poor global fossil record of dinosaurs remaining in the Middle Jurassic coincides with a time of significant diversification in dinosaur evolution [1-4]. However, the wealth of dinosaur prints (tracks) discovered from the north of England (Yorkshire) and west of Scotland (Isle of Skye) is potentially useful in recognizing the diversity of dinosaurs that inhabited these two regions during this time period (Figure 1).

Exposures of Middle Jurassic rocks in the two regions are dominantly coastal, and therefore of limited areal extent. Thus, the longest fossil dinosaur trackway recorded in the Cleveland Basin reaches no more than $13 \mathrm{~m} \mathrm{[5]}$, and even less $(5 \mathrm{~m})$ in the Hebrides Basin. These lengths are insignificant compared with those from inland exposures in America (215 m) [6], Portugal (147 m) [7] and many others [8,9]. However, an advantage of coastal over inland exposures is that fresh rock from sea erosion and cliff falls is continuously being replenished at a faster rate than normally seen in terrestrial 
environments, thus frequently yielding new finds. However, coastal exposures have inherent problems of accessibility and tide restrictions.

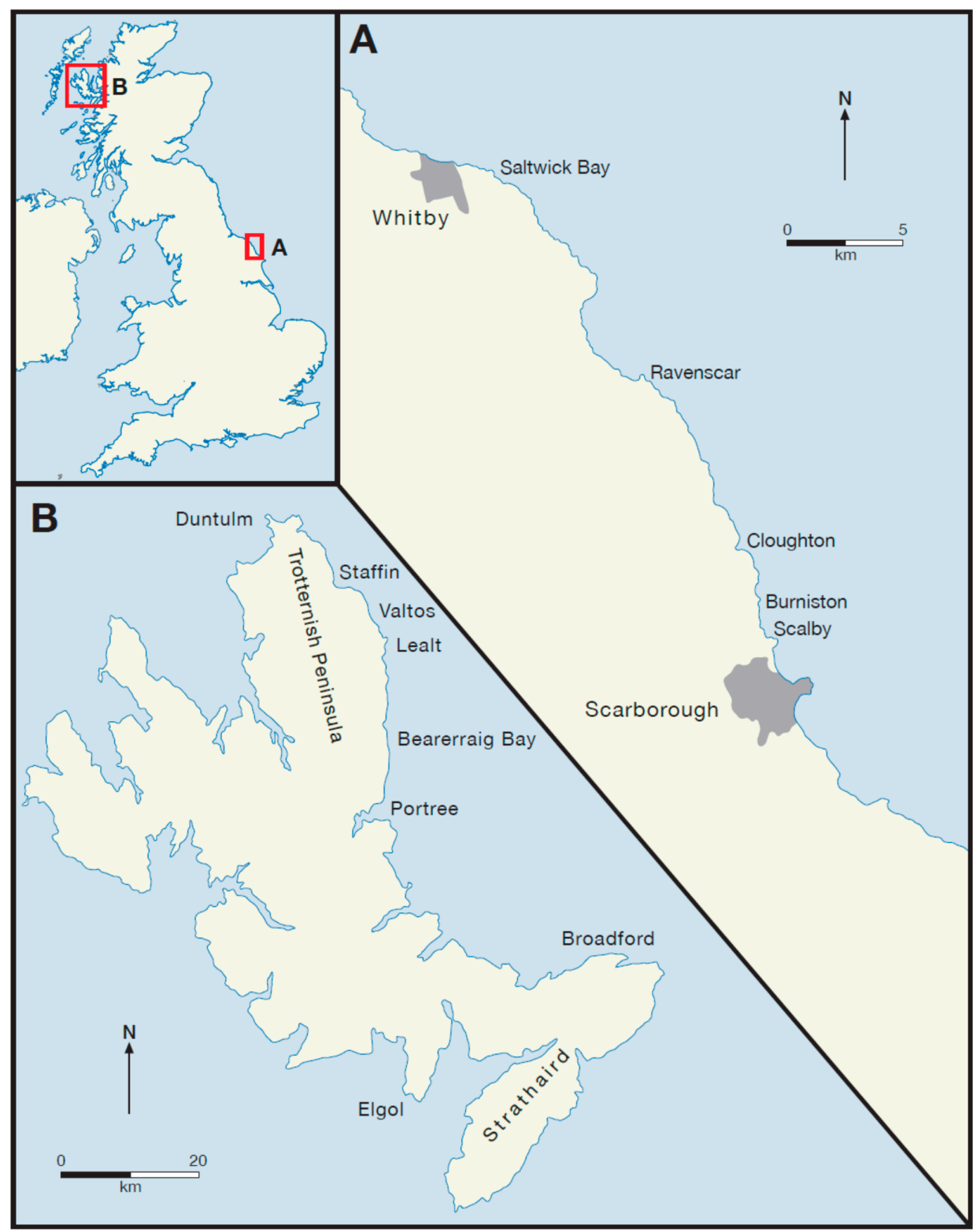

Figure 1. Location maps of Yorkshire (A) and Isle of Skye (B) showing localities of place names and formation names mentioned in the text.

\section{Palaeogeography in the North of Britain during the Middle Jurassic}

In Yorkshire, rocks of Middle Jurassic age (Aalenian to Bathonian) constitute the Cleveland Basin, while on the Isle of Skye (Aalenian to Callovian) they form part of the Hebrides Basin, a composite basin including the Canna Basin and Coll Basin within the Little Minch Trough south of the Minch Fault, and the Inner Hebrides Basin south of the Skerryvore and Camasunary faults [10]. During this time, much of Skye was a coastal topographic high known as the Skye High [11,12], with a number of transgressive and regressive sequences throughout the Aalenian to Callovian [13]. In Early Jurassic times, the Cleveland and Hebrides basins were part of a generally shallow shelf sea, with a large area of land over Scotland made up of the northern Shetland Platform and a connected southern Scottish Landmass (Figure 2A) [14]. By early Middle Jurassic times, following the late Aalenian marine 
transgression, an emergent Mid North Sea High had developed adjacent to the Scottish Landmass, and the Pennine Landmass formed an extension of the Scottish landmass further south. These latter two landmasses provided the source for sediment from rivers draining off into the start of the Cleveland Basin depocentre (Figure 2B). More or less contemporaneously, the Hebrides Basin developed off to the west of the Scottish Landmass with sediment being derived from this source, but isolated from the Cleveland Basin and possibly with no coastal plain contact with it (Figure 2B). This scenario was maintained without any major changes throughout the rest of the Middle Jurassic, except that occasionally coastal plains were possibly more extensive and could be traced continuously from one basin to the other (Figure 2C,D).
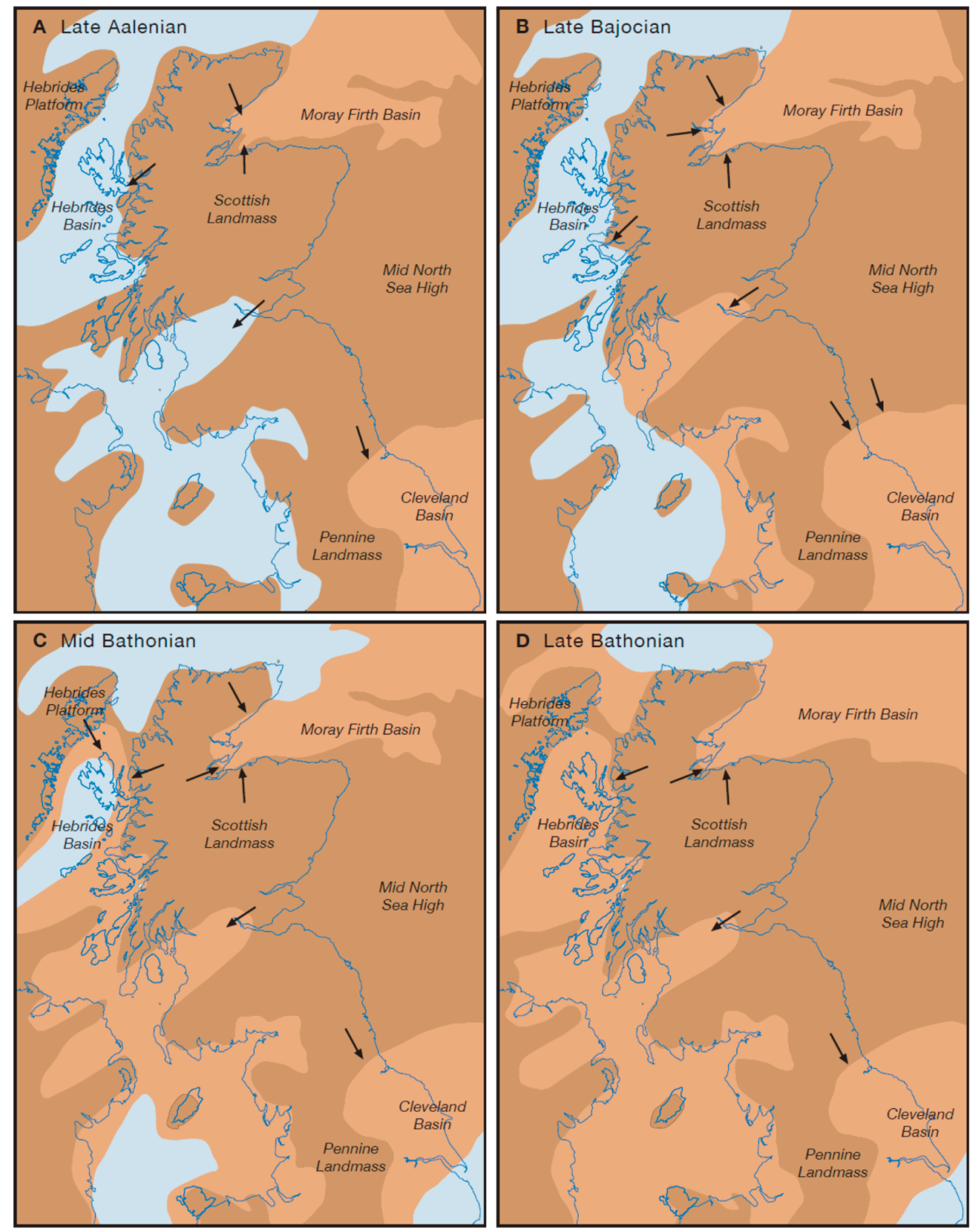

Figure 2. Palaeogeographic maps of the Cleveland and Hebrides basins during the Middle Jurassic [14]. (A) Late Aalenian, (B) Late Bajocian, (C) Mid Bathonian, (D) Late Bathonian. Brown-erosional areas, yellow-alluvial plains, deltas, blue-shallow seas. CB-Cleveland Basin. HB-Hebrides Basin, MFB-Moray Firth Basin, PL-Pennine Landmass, SL-Scottish Landmass, HP-Hebridean Platform, MNSH-Mid North Sea High (arrows show main direction of sediment deposition). 
These two basins in the Middle Jurassic were at least $400 \mathrm{~km}$ apart, separated by landmasses, which, though providing clastic sediment for the basins, were not of sufficient height (nor subjected to such intense climatic conditions) as to provide much coarse-grained sediment to the basins. The general absence of coarse-grained sandstones and siliciclastic clasts in the Middle Jurassic sediments of the Cleveland Basin suggest that they were deposited in an area of low available relief and relatively low flow regimes. The sediments of the Hebrides Basin also lack the coarse-grained sandstones with the first minor lenticular quartz pebble conglomerates, derived from the west, appearing in the Brora Sandstone Member of the Brora Arenaceous Formation (Oxfordian) near Brora, although the late Bathonian Skudiburgh Formation also contains intraformational conglomerates at Port Duntulm, Isle of Skye $[15,16]$. The terrestrial trace fossils found in the two basins indicate that diverse dinosaur communities existed in both.

\section{Comparison of Middle Jurassic Lithostratigraphy and Facies of the Cleveland and Hebrides Basins}

The dinosaur print-bearing units from the Middle Jurassic sequences of the Cleveland Basin range from Aalenian to Bathonian in age, and are assigned to the Ravenscar Group, a unit approximately $220 \mathrm{~m}$ thick and comprising five formations (Figure 3). The sequence is dominantly non-marine, consisting of sandstones and mudrocks, impure coals and ironstones, but interbedded with three marine units which contain impure argillaceous limestones and marine shelly faunas. The Bathonian dinosaur print-bearing strata on the Isle of Skye is approximately $250 \mathrm{~m}$ thick and belongs to the Great Estuarine Group (Figure 3). The Skye sediments are also a complex interplay of coarse and fine-grained siliciclastic sediments lagoonal, fluvial of varying salinities [13]. Both basins are formed of sediments of the optimal consistency for the preservation of dinosaur footprints $[17,18]$.

The rocks of the Ravenscar Group are now generally regarded as being a coastal plain and fluvial complex [19], represented by paralic fluvial and lacustrine lithofacies (Saltwick, Cloughton and Scalby formations) with three marine intercalations (Eller Beck Formation, a locally developed Lebberston Member within the Cloughton Formation, and Scarborough Formation) [20,21]. However, as pointed out by Eschard and others [22,23] some sedimentological features may also suggest a deltaic origin for parts of the sequence. The ribbon sheet sandstones of the non-marine units represent crevasse splays and levee deposits, while thicker saucer-shaped sandstone bodies indicate lenticular channel sandstones. The thick mudrocks interbedded within the sequence may have accumulated in flood plains, shallow lakes and marshes, brackish lagoons or abandoned river channels. Locally, peaty mires accumulated, thick enough to form thin coals [21]. Plant remains such as ferns and horsetails are very common and diverse [24] and occur as drifted leaves [25], transported logs and in situ erect stems, while conifer remains were transported into the basin from the hinterland. However, invertebrate body fossils are very rare. Only bivalves (Unio) have been recorded from the Saltwick and Scalby formations, and bivalve escape structures (Lockeia) are common. Other invertebrate traces from the non-marine units are locally more abundant, and include Cochlichnus, Protovirgularia, Beaconites (? = Taenidium) [26], Selenichnites [27-30], Kouphichnium [31,32], Diplocraterion and simple burrows.

The Great Estuarine Group on Skye is represented by the Cullaidh, Elgol, Lealt Shale, Valtos Sandstone, Duntulm, Kilmaluag and Skudiburgh formations. The underlying Bearerraig Sandstone (Aalenian-Bajocian) exhibits two major transgressions that are also evident in the Cleveland Basin [33]. This formation represents a period of marine water cooling by as much as $10^{\circ} \mathrm{C}$ perhaps as a result of thermal doming and resulting changes to ocean currents [34]. The Great Estuarine Group has two main phases of sand deposition separated by muddier sediments and terminating with the fluvial deposits of the Skudiburgh Formation (channel sands, muds and calcrete) [13,35]. The sandbodies of the Valtos Sandstone Formation represent lagoonal shorelines and deltas prograded from north to south as they did in the earlier part of the Great Estuarine Group on Skye during the deposition of the Elgol Formation [13,36]. 
The muddier horizons within the Great Estuarine Group on Skye generally represent lagoonal conditions. The Lealt Shale Formation represents a brackish lagoon, whereas the mudstones of the Duntulm Formation are brackish to more normal marine salinities and the Kilmaluag Formation is predominantly freshwater $[13,35,36]$. The environment of deposition within the Duntulm Formation is complex and has been interpreted as ranging from freshwater carbonate muds and sands, supralittoral carbonate algal marshes, brackish-marine lagoons with an abundance of the fossil oyster Praeexogyra hebridica [37], small prograding delta sands and, towards the top of the formation, freshwater muds and sands [38,39]. Some of the trackway surfaces in the Duntulm Formation are rippled and do not appear to exhibit desiccation cracks that are commonly seen in the Valtos and Kilmaluag formations and contains abundant Diplocraterion trace fossils [39,40]. At the end of the Great Estuarine Group on Skye, a more off-shore marine environment existed by the Middle Callovian caused by a widespread change in relative sea-level with mudstones in the Trotternish area and marine sandstones in the Strathaird Inner Hebrides Basin [13].

A

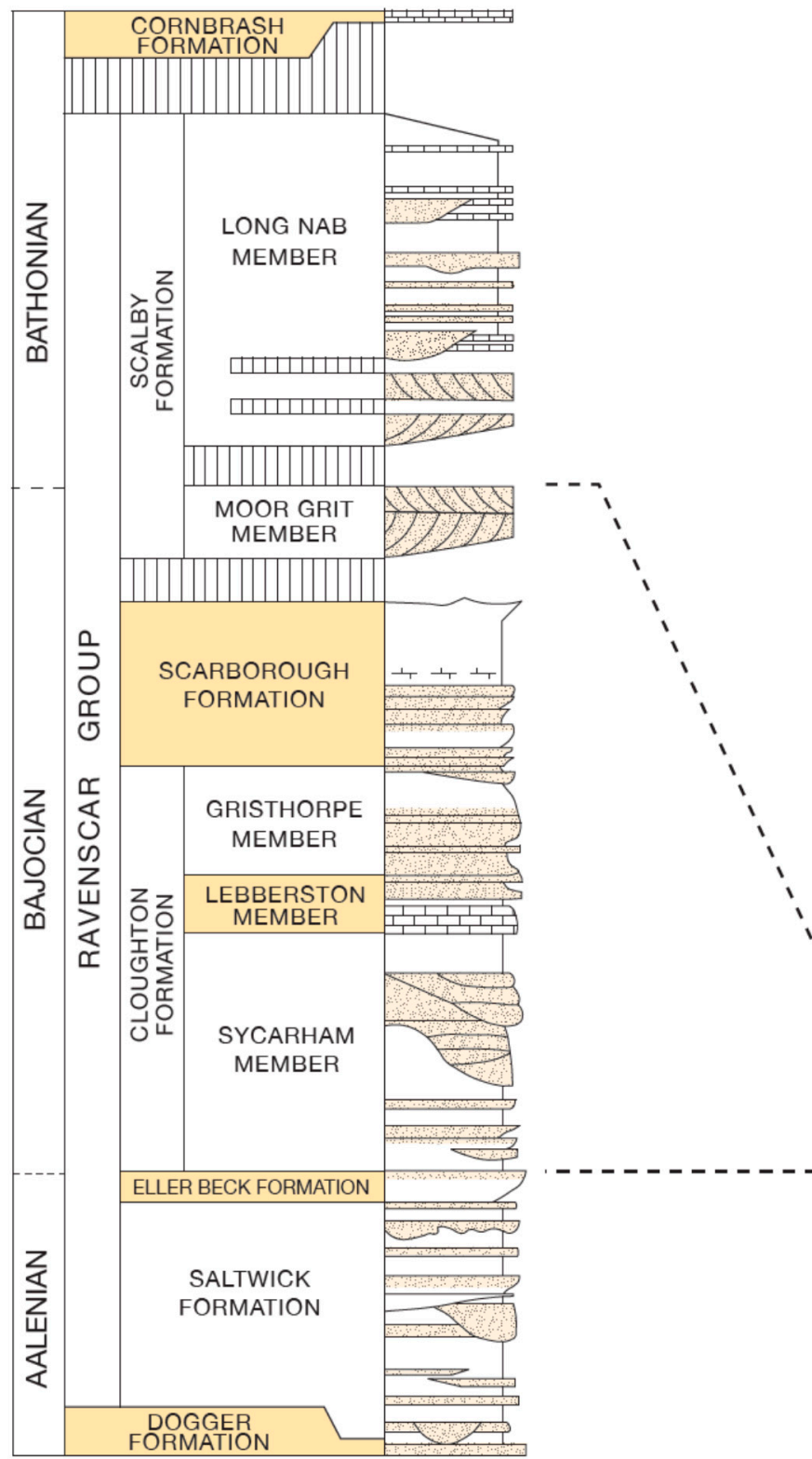

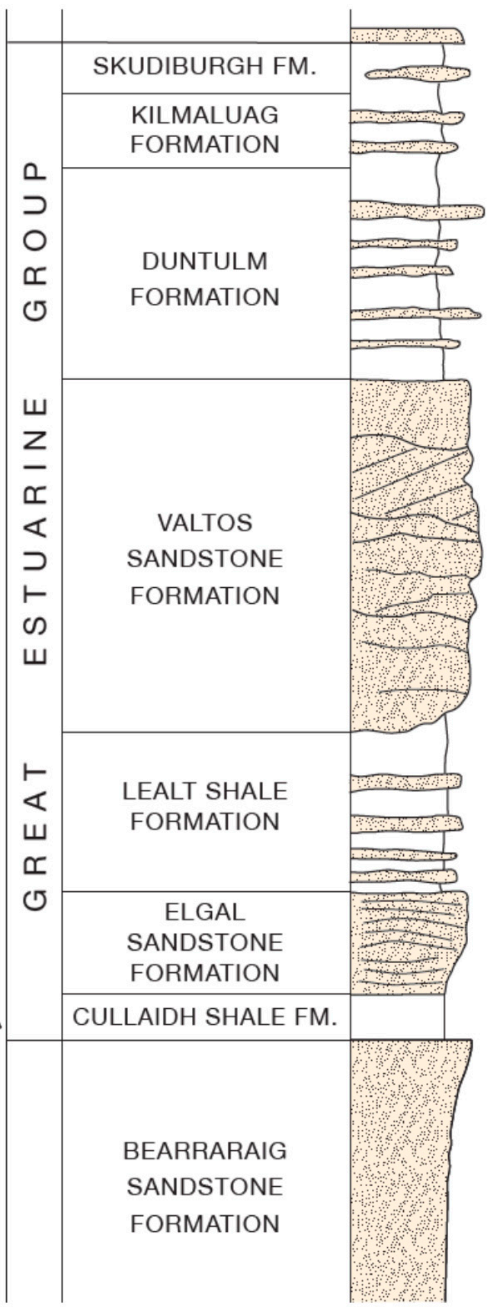

Figure 3. Middle Jurassic lithostratigraphy of the Cleveland (A) and Hebrides basins (B). 


\section{Dinosaur Body Fossils of the Cleveland and Hebrides Basins}

Dinosaur body fossils are rare from the Middle Jurassic Ravenscar Group of the Cleveland Basin. The first record of such material was from White Nab, near Scarborough. This was described by Williamson [41] who assigned one of the bones, a fragment of a vertebra, as possibly 'Megalosaurus'; paradoxically the specimens were from the marine Scarborough Formation. Unfortunately, Williamson's material cannot now be confidently identified [42]. There were no further records published of dinosaur bones from the Middle Jurassic of Yorkshire until the Sheffield Dinosaur Track Research Group (see below) began work on dinosaur trace fossils from the area. These finds were tabulated by Romano and Whyte [5] when four new horizons were identified. Seven years later, the number of horizons with skeletal finds had increased to eight [42], most of these from channel deposits. However, among these, the most significant is an isolated caudal vertebra, from a palaeosol in the Saltwick Formation, of an early sauropodomorph that is at present the earliest stratigraphic occurrence for a British sauropod dinosaur [43]. Although new finds are continually being reported, it still remains an enigma that they are comparatively rare, and particularly in the complete absence of teeth. This may be due in part to 'rapid solution by the acidic groundwaters and seasonally high water tables that are made evident by the sphaerosiderite-rich, gley palaeosols' [42].

Body fossils are also rare in the Hebridean area, although there are quite a few different groups represented by the bony remains [44]. The first bone to be found was a partial theropod tibia from the Sinemurian (Early Jurassic) of Strathaird, but every body-fossil found since then has been from the Great Estuarine Group in both Trotternish and Strathaird. Many of the bones found have not been diagnosable beyond dinosaur, but several have been assigned to different groups. The first Middle Jurassic dinosaur body fossil to be described from the Isle of Skye was a limb-bone, possibly the left humerus, of a basal eusauropod [44-47] from the Valtos Sandstone Formation. Further remains from this formation included a caudal vertebra [46] a rib bone and a tooth [47] all of which belong to a primitive eusauropod. A further sauropod tooth found in the Strathaird section of the Kilmaluag Formation could also belong to a primitive eusauropod or a basal titanosauriform [48].

Theropod remains are very rare in the Hebrides Basin with only a few teeth fragments and a single caudal vertebra [49]. The tooth is thought to representative of either a megalosaurid, basal tyrannosauroid, or dromaeosaurid, and that the vertebra may belong to a small-bodied basal coelurosaur [49]. However, both of these remains lack the diagnostic characteristics that would allow confident assignment to any particular clade and have been left as Theropoda indet [49]. The only other theropod remains recorded is a tooth fragment from the Fish Bed of the Lealt Shale Formation on the Isle of Eigg [50].

The only other dinosaur body fossil that has been described from the Middle Jurassic of Skye is a proximal ulna and radius of a thyreophoran dinosaur, perhaps a basal europodan akin to either the ankylosaurs or stegosaurs [51]. This was found in the older Bajocian Bearerraig Sandstone Formation near Storr Lochs on the Trotternish Peninsula of the Isle of Skye in association with a possible humerus that was subsequently removed by a collector before the local museum was able to retrieve it [51].

There are many bone fragments, teeth, and more complete bones awaiting preparation and description in the collections of the Hunterian, the National Museums of Scotland and the Staffin Museum. These are currently being studied by the PalAlba group, a consortium of researchers based in Scotland.

\section{Brief History of Dinosaur Ichnite Research from the Cleveland and Hebrides Basins}

The first record of vertebrate tracks from the Cleveland Basin was in the early twentieth century when Hargreaves [52] reported that a track found by Mr Rowntree about 18 years earlier from south of Scarborough had been identified by Mr Lamplugh as 'probably crocodilian'. It is more likely that it was made by a dinosaur, although since the specimen has not been traced it has not proved possible to confirm this [41]. 
Brodrick was the first to describe dinosaur tracks from the Cleveland Basin in a series of papers [53-56]; all the tracks were of tridactyl forms and were from outcrops around Whitby (Saltwick Formation of Aalenian age, see below). The recording of new finds then declined, following the onset of World War 1 and World War 2 [42], and only began to show some renaissance by the mid 20th century $[52,57]$. However, it was not until the latter part of the 20th Century that interest was rejuvenated, when Sarjeant [58] described Satapliasaurus dsocenidzei Gabouniya [58], the first named dinosaur ichnite from the Cleveland Basin. Valuable contributions from amateur geologists [59] followed, and increasing numbers of papers were published on new finds from units of Aalenian to Bajocian age, particularly by the Sheffield Dinosaur Track Research Group [42] who began the modern phase of ichnological studies [42,60-66]. A distinctive second dinosaur ichnite from the Cleveland Basin was subsequently described [60] but was not formally named as Deltapodus brodricki until two years later [61]. At about this time, further new prints were described from the area and were referred to Brontopodus-like and Breviparopus-like [65], soon followed by the recognition and description of dinosaur swimming tracks (Characichnos tridactylus) [62].

The history of dinosaur track research in the Hebrides Basin is in contrast to that in the Cleveland Basin. It was not until 1982 that the first dinosaur footprint (a single track of a purported ornithopod) was found from the Lealt Shale Formation (Bathoninan, see below) at Trotternish, Skye. This was reported in The Scotsman newspaper [67] and a full description was subsequently published in 1984 [68]. Since then, many more footprints at other localities have been found and recorded from other units of Bathonian age $[39,40,45,69-72]$.

It is interesting to note that, on both the east Yorkshire coast and on the Isle of Skye, workers had for many years been undertaking research on other aspects of the geology without either noticing the prints, or considering them not significant or important enough to study! The recent years have happily countered this omission, resulting in that both areas are now considered significant on a global scale to help bridge the gap in our knowledge of dinosaurs during the Middle Jurassic.

\section{Dinosaur Ichnology of the Ravenscar Group of the Cleveland Basin and Great Estuarine Group of the Hebrides Basin}

By the early part of the present century, 25 dinosaur print morphotypes had been identified from the Cleveland Basin [5,18] (Figure 4A). At that time, the authors preferred not to refer to the different prints as ichnospecies, nor to regard the brief descriptions as diagnoses, since the general lack of trackways and paucity of a number of the print types prevented any clear conclusions as to whether they represented true ichnospecies or were preservational variants. The 25 morphotypes were divided into three groups: Group A-prints made by quadrupeds, Group B-prints made by bipeds, and Group C-swimming prints [5,18].

Group A included five (Ai-v) different morphotypes. Morphotypes Ai and Aii had previously been referred Brontopodus-like and Breviparopus-like respectively [66]. Four years later, because of the general scarcity of manus-pes couples and trackways of prints of these types, these two morphotypes were still only listed as 'Brontopodus' and 'Breviparopus' [18]. By 2012, a number of additional manus tracks had been recognized, yet none of these showed the 'somewhat U-shaped' manus outline of Brontopodus birdi, the type ichnospecies of Brontopodus [73]. The five morphotypes Ai-v are now referred to the following ichnotaxa: Ai-Brontopodus ichnosp.; Aii, Aiii-Breviparopus-like ichnosp. [65]; Aiv-Ichnogen et ichnosp. indet [64].

The final print morphotype in Group A (Av) was assigned to a new ichnotaxon, Deltapodus brodricki [61], after the distinctive 'delta-shaped' pes imprint and the name of the person who first described dinosaur prints from the area. This print type has now been recognized across the Jurassic world and has been recorded from Spain, Portugal, Morocco and Utah (USA) [74], and most recently in the Cretaceous of China [75]. 


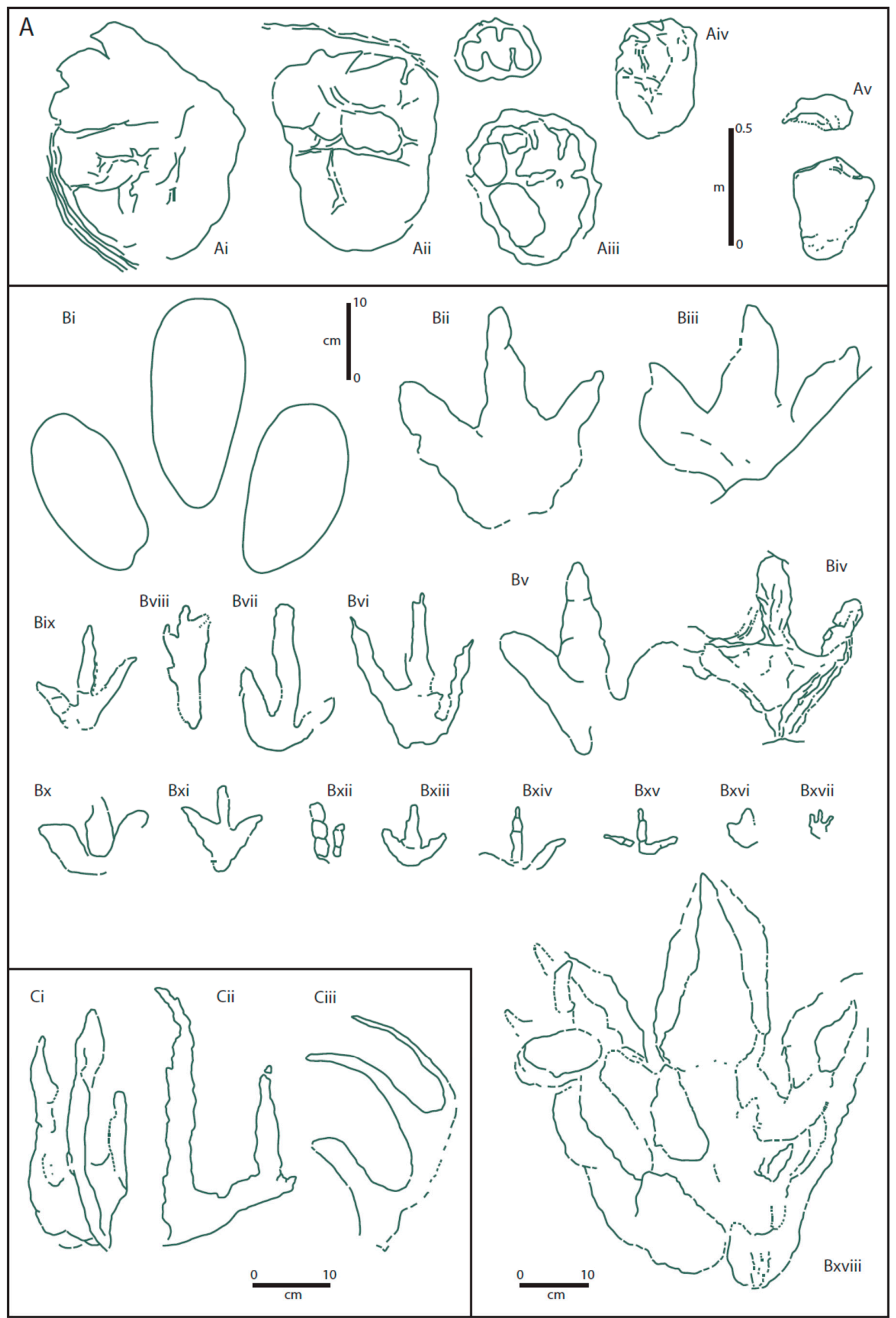

Figure 4. Cont. 


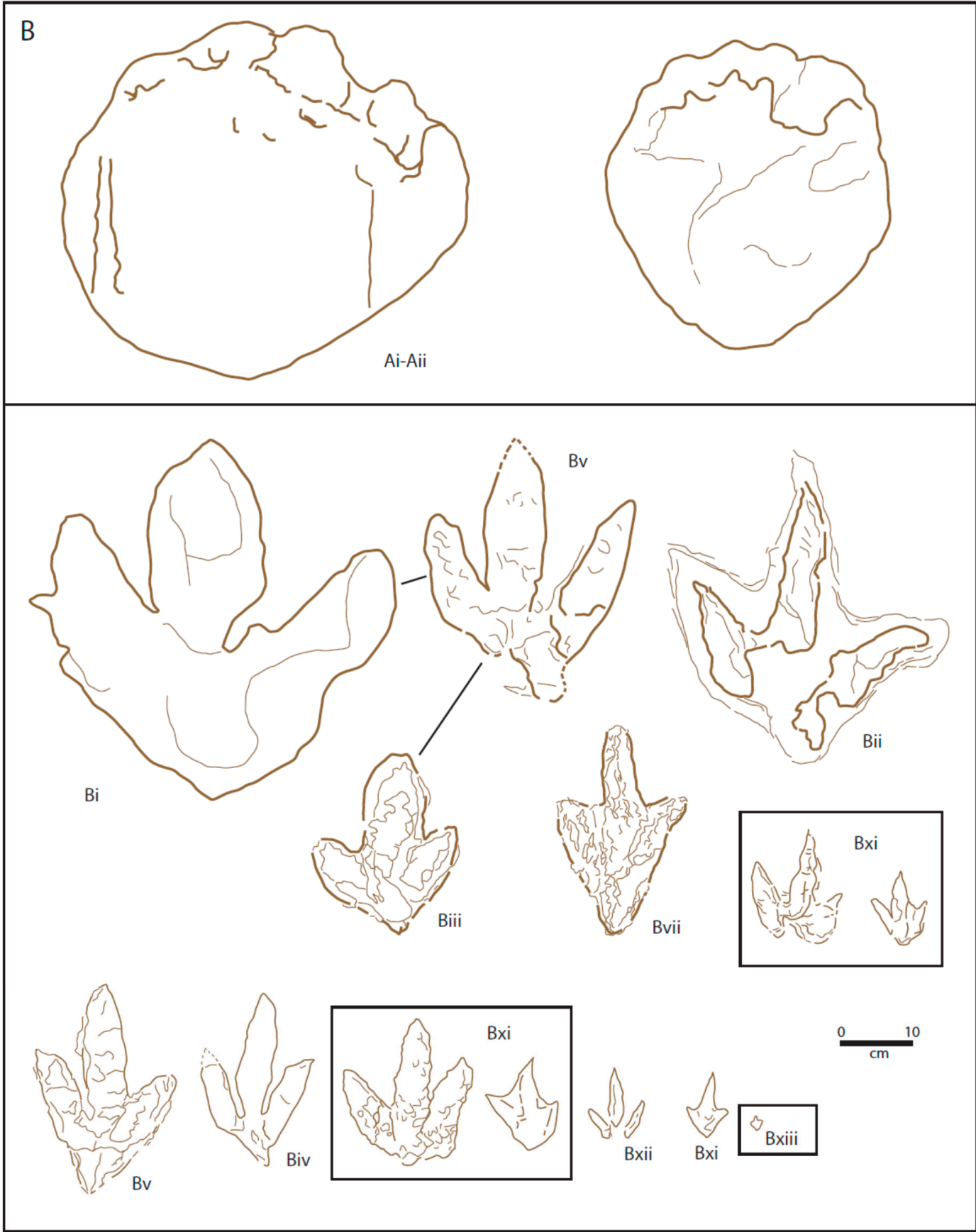

Figure 4. Dinosaur print morphotypes from the Cleveland Basin (A) $[5,18]$ and Hebrides Basin (B) $[39,40,44,47,69,70]$. The top three morphotypes in (B) are from the Lealt Shale, Valtos Sandstone and Duntulm formations respectively; the middle four are from the Duntulm Formation (left-Biii) and the Valtos Sandstone Formation; and the lower seven are from the Kilmaluag Formation.

Group B contained 17 tridactyl prints that had been made by bipeds (Figure 4). While nearly all are certainly pes prints, Bxvii is most probably a manus print [5]. Only one (Satapliasaurus dsocenidzei-Biii) was named at that time [58], although this identification was questioned by Lockley and Meyer [8] who suggested that it should perhaps be treated with caution, while one other (Bxii) was assigned to cf. 'Grallator'. Since then, other prints in Group B (Bii, Bv, Bxii and more recently, Bxviii) have been tentatively assigned to a named ichnotaxon, such as Eubrontes, Megalosauropus or ichnotaxa from the Anchisauripus-Grallator series [76,77]. The most recently found large print Bviii followed the recording 
of even larger tridactyl tracks that had been sporadically found from the Scalby Formation [59,78]. The problem of whether the remaining prints in Group B may be assigned to distinct ichnospecies is illustrated with respect to print types Bix, Bviii and Bxi. All three of these print types were made by the same animal in an ichnoassemblage that shows prints with a range of morphologies [8]. Print type Bviii shows imprints of the metatarsal area [5], which resulted from the animal sinking lower in the sediment and so recording the greatest degree of metatarsal extension. Had a trackway been formed entirely of this type of print (Bviii), it would have been justified in naming the trackway; but an isolated print of this type within an assemblage of prints of varying morphologies does not provide the ichnotaxonomic basis for giving Bviii a different or new name.

Among the most distinctive tridactyl prints in Group B are the small, gracile prints Bxiv and Bxv (Figure 4), with slender digit prints, showing evidence of phalangeal pads and very wide divarication. Though distinctive, their rarity has not allowed a complete understanding of their morphology, and so they have not been assigned to any ichnotaxon.

Within Group C (swimming group), print type Ci had earlier been described and named as Characichnos tridactylus [62]. The two other print types in Group C, Cii and Ciii (Figure 4), were later reinterpreted as part of a trackway which was produced by the same animal type as that which made Deltapodus brodricki (see below). These print types were assigned to Characichnos isp. on the grounds that the limited number of prints in the trackway is insufficient to propose a new ichnospecies [79].

No attempt has been made to define all the footprint morphotypes in the Hebrides Basin (Figure 4B), but comparative morphometric analyses have been carried out to differentiate different tridactyl tracks using principal component analyses on non-subjective landmarks [40,70,72]. As a result three different tridactyl tracks were distinguished on this basis $[40,70,72]$. The first, and most abundant footprint type are the smaller ( $<20 \mathrm{~cm}$ length) footprints from the Valtos Sandstone and Kilmaluag formations (Table 1. X; Figure 4B-morphotype Biii, Biv, Bv, Bvii, Bxi, Bxii, Bxiii). The second are the larger footprints from the Valtos Sandstone Formation (Table 1. Y; Figure 4B Bv) and also includes the first dinosaur footprint to be found on Skye from the Lealt Shale Formation (Figure 4B Bi); and the third group of tridactyl tracks are those large tracks found in the Duntulm Formation (Table 1. Z; Figure 4B Bii). A potential fourth group could not be analysed as it is represented by a single footprint from level B in the Duntulm Formation at An Corran (Table 1. W; Figure 4B Biii).

These footprints can also be looked at in terms of the morphotypes recognized from the Cleveland Basin [18]. Variations in footprint preservation may be related to differences in the consistency and type of sediments between the Cleveland Basin and the Hebrides Basin. The footprint from the Lealt Shale Formation is about $49 \mathrm{~cm}$ long with broad digit impressions similar to morphotype Bi-Bii [18]. In the Valtos Sandstone Formation, there are three size groups of tridactyl footprints; one based on a single track measuring over $100 \mathrm{~cm}$ in length, one large at about $40 \mathrm{~cm}$ in length, and another small at up to $28 \mathrm{~cm}$ in length [45]. The first group is similar to the footprint from the Lealt Formation with large rounded digit impressions (Bi-Bii) and the other group are smaller tridactyl footprints ranging in size from 17 to $24 \mathrm{~cm}$ in length (Bv) [69]. Only one small (40 cm long) sauropod footprint is known from the Valtos Formation [47]. The footprint is possibly closest to the Aiv morphotype [18], although it is unclear whether the digits curve at the straight anterior margin.

The larger tridactyl footprints at level A from the Duntulm Formation at An Corran appear to contain morphotypes Bii or $\mathrm{Bv}$ in terms of shape although they are larger than these morphotypes described from the Cleveland Basin at between 32 and $53 \mathrm{~cm}$ in length. From the same formation at level B at An Corran, a single footprint resembles more morphotype Biii and is $24 \mathrm{~cm}$ in length [18,70]. The large ( $\sim 70 \mathrm{~cm}$ long) sauropod footprints from the Duntulm Formation at Cairidh Ghlumaig are similar to the Aii morphotype described as Breviparopus-like $[18,39,66]$.

In the Kilmaluag Formation of Lub Score on the western side of the Trotternish Peninsula, the footprints vary greatly in size probably due to the co-existence of adult and juvenile of the same species. The footprints can range from 1.8 to $27 \mathrm{~cm}$ in length and their impressions are similar to morphotypes Bv and Bxiii [72]. 
To date, no swimming tracks (see Group C morphotypes of the Cleveland Basin, Figure 4) have been recorded from the Great Estuarine Group of Skye. This is perhaps difficult to explain since they are relatively common throughout the Ravenscar Group [77] and yet similar facies occur in both basins.

Table 1. Dinosaur footprint morphotypes [5] and groupings based on principal component analysis (PCA) by formation from the Hebrides Basin [72].

\begin{tabular}{ccc}
\hline Formation & Morphotypes Present & PCA Groups \\
\hline Kilmaluag Formation & Bv and Bxiii & X \\
Duntulm Formation & Bii or Bv, Biii and Aii & Y, W \\
Valtos Formation & Bi-Bii, Bv and Aiv & X, Z \\
Lealt Formation & Bi-Bii & Z \\
\hline
\end{tabular}

\section{Distribution of Print Types with Respect to Facies and Age}

Prints within the Cleveland Basin are preserved in a variety of ways and in different facies $[18,80]$. Transmitted and underprints are most common, while surface prints less so [5]. In addition, the facies in which they occur are extremely variable. Prints are most commonly found at the base of often thin, sheet sandstone beds ('Burniston footprint bed' of Hargreaves [57]; and 'Deltapodus sandstone' of Romano and Whyte [18]), which are frequently the result of crevasse splays. However, the positive hypichnial prints, which protrude beneath the undersurface of these beds, were commonly not made at the interface between the underlying mudrocks and overlying sandstones. Sectioning through these prints [18] frequently reveals the true tracking surface higher up (later) in the sequence. This then brings into question whether the animals that lived in the area preferred a sandy instead of muddy substrate on which to move around. Unfortunately, the frequently thick homogeneous mudrock sequences (often over a metre in thickness) will not yield evidence of foot emplacement in the absence of beds with contrasting sediment grain size. Consequently, the well-known 'footprint beds' are often the result of underprinting from a higher level.

Despite these apparent anomalies, the distribution of prints within sequences of varying facies indicates that the dinosaurs of the Cleveland Basin frequented the tops and slopes of point bars [77], river levee deposits and interdistributary areas. In addition, they also probably inhabited the margins of waterholes, as made evident by the occasionally extensive and frequent dinoturbated beds [18]. It is noteworthy that the relatively common prints attributed to sauropods occur in siliclastic facies, yet have frequently been linked to more marginal marine habitats $[1,81]$.

The tridactyl footprints from the lowest unit of the Hebrides Basin (Lealt Shale Formation) are associated with more muddy environments, but may represent undertracks making it difficult to be certain of the sediment on which the animals walked [68]. In the Valtos Sandstone, Duntulm and Kilmaluag formations, the tridactyl footprints are commonly associated with desiccation cracks that emanate from the digits suggesting that the animals walked on a damp substrate prior to the cracks forming $[38,40,69,70,72]$. Further lithological studies are being carried out on new tracksites, including the sauropod tracksite of the Duntulm Formation, which may help elucidate the life environment of the trackmakers [39]. The general environment appears to show a series of lagoons with some footprints in the Duntulm and Kilmaluag formations on rippled surfaces indicating that the animals walked on a higher energy sandy lagoon shoreline as well as the muddier low energy environments $[38,40]$. The sauropod prints in the Duntulm Formation were described as being made by animals wading in very shallow lagoonal water [39].

The distribution of prints throughout the stratigraphic range is more difficult to quantify. Their distribution in the Cleveland Basin (Figure 5) is based on concentrated work in the area over the past 20 years or so, but is influenced by exposure and accessibility, as well as spatial and temporal heterogeneity within the succession [77]. Thus, the absence of prints from a particular horizon may be due in part to a sampling deficiency or a result of behavioural or environmental control. The former category almost certainly explains the general lack of recorded prints from the Cloughton Formation, 
as well as the relatively high numbers of prints from the relatively accessible Saltwick Formation and Long Nab Member of the Scalby Formation. The distribution of print types shown as pie charts for the Scalby Formation on the foreshore of Scalby Bay [77], where prints have been recorded within the top 1-2 $\mathrm{m}$ of the unit, show a degree of heterogeneity that may be real rather than a purely preservational bias.

\section{CLEVELAND BASIN}

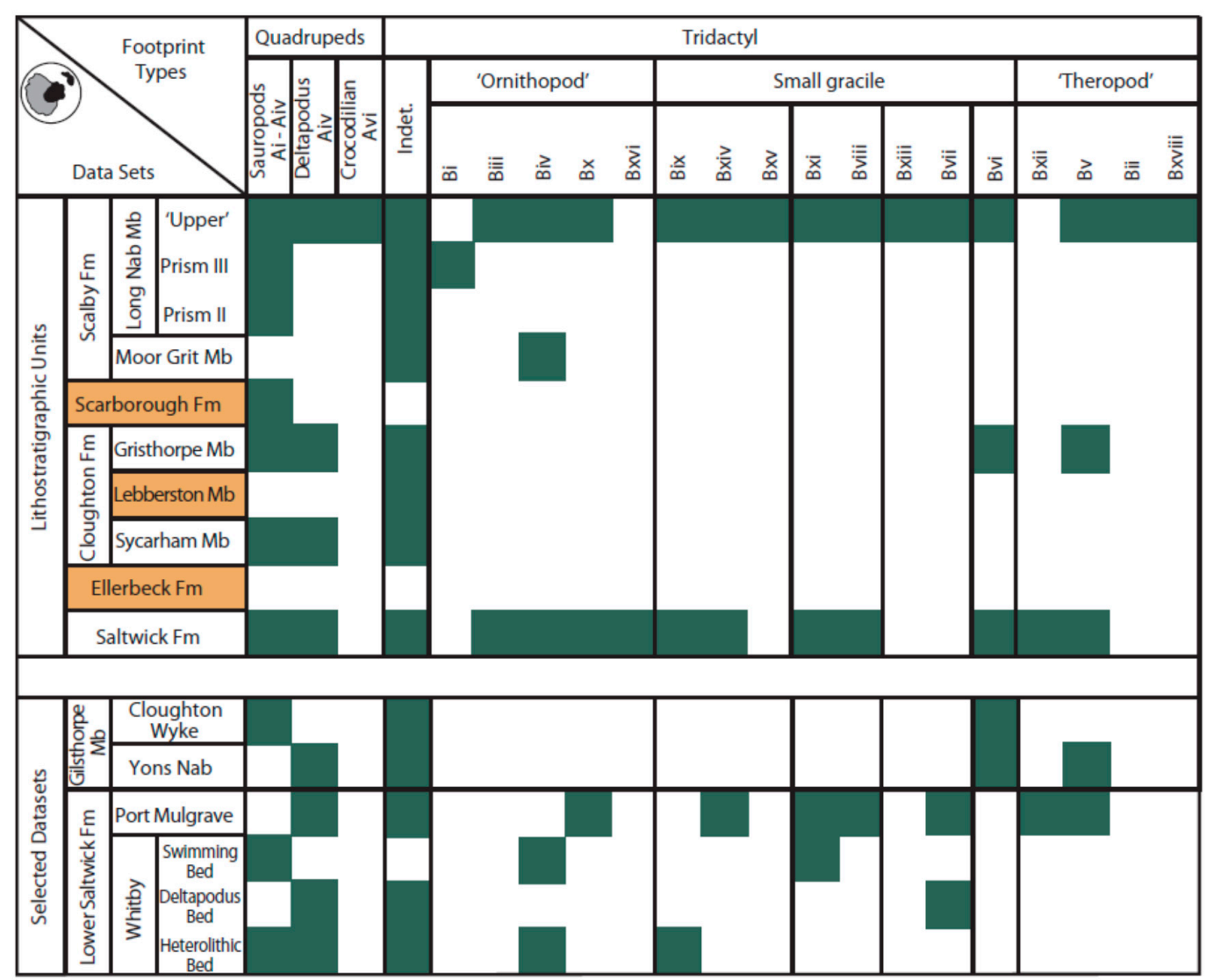

HEBRIDES BASIN

\begin{tabular}{|c|c|c|c|c|c|c|c|c|c|c|c|c|c|c|c|c|c|c|c|c|}
\hline & \multicolumn{2}{|c|}{ Quadrupeds } & \multicolumn{18}{|c|}{ Tridactyl } \\
\hline Foot & \multirow{2}{*}{ 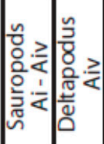 } & \multirow{2}{*}{ 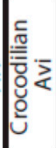 } & \multirow{2}{*}{$\begin{array}{l}\text { 苞 } \\
\underline{\underline{0}}\end{array}$} & \multicolumn{5}{|c|}{ 'Ornithopod' } & \multicolumn{8}{|c|}{ Small gracile } & \multicolumn{4}{|c|}{ 'Theropod' } \\
\hline & & & & $\bar{\omega}$ & 狺 & 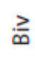 & শ্口 & ¿্ৰ & 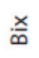 & 䏒 & \্ৰ & $\bar{\infty}$ & $\sum_{\infty}$ & : & : & $\bar{\infty}_{\infty}$ & : $\overline{\bar{x}}$ & वे & : & : \\
\hline Kilmaluag Fm & & & & & & & & & & & & & & & & & & & & \\
\hline Duntulm Fm & & & & & & & & & & & & & & & & & & & & \\
\hline Valtos Sandstone Fm & & & & & & & & & & & & & & & & & & & & \\
\hline Lealt Shale Fm & & & & & & & & & & & & & & & & & & & & \\
\hline
\end{tabular}

Figure 5. Distribution (presence-absence) of dinosaur tracks from the Middle Jurassic Ravenscar Group of the Cleveland Basin and Great Estuarine Group of the Hebrides Basin.

The vertical distribution of prints in the Hebrides Basin (Figure 5) is also difficult to quantify as there are only a few recorded sites thus far and most tracks are found on loose blocks on the foreshore below high vertical cliffs or eroding out of old landslips. For example, there is only one footprint recorded from the Lealt Shale Formation found near Brothers' Point thus far [68] and the stretch 
of coastline between Brothers' Point and Dun Dearg is where most of the footprints of the Valtos Sandstone Formation have been found in loose blocks $[47,72]$. The spatial distribution of the footprints in the Valtos Sandstone Formation is difficult to assess as no precise horizon for the dinosaur remains has yet been established although the greatest variety of print types are found in this formation. Two localities are currently known for in situ Duntulm Formation prints: an Corran near Staffin from which the larger tridactyl prints are found; and the sauropod footprints of Cairidh Ghlumaig near Duntulm Castle. Both these localities are described as essentially monospecific although a poorly preserved tridactyl footprint was found at Cairidh Ghlumaig [39] and an unidentified single small round footprint was found at an Corran [70]. Only tridactyl footprints were found at Score Bay in the Kilmaluag Formation all of which may have been formed by one trackmaker species as they were indistinguishable based on their morphometrics using landmark analysis [40]. A few footprints were found in situ at this locality. Precise correlation between localities are also quite difficult on the Isle of Skye as the sediments have been disrupted by multiple injections of Palaeogene igneous intrusions that jump between layers. This coupled with the discontinuity of layers, footprints being found mostly on loose blocks and lack of good continuous exposure make it impossible to be certain as to which precise horizon many of the prints derived from.

\section{Animal Makers of Dinosaur Prints from the Cleveland and Hebrides Basins}

Although it may be a primary objective to identify the dinosaur responsible for those making the prints, in reality, this is perhaps the most difficult, and often unsolvable part of the study of vertebrate palaeoichnology. Indeed, 'tracks have a relatively low taxonomic resolution and are usually not attributable below the family level' [82]. Unlike similar studies in invertebrate palaeoichnology, where a number of examples are known where the maker is preserved intimately associated with the prints (Kouphichnium and limulid [83], Rusophycus and trilobite [84], Lockeia and bivalve [85]), such instances have never, as far as the authors are aware, been documented in the dinosaur ichnological record (other than the possible protoceratopsid with tracks from Mongolia [86]). However, by studying well-preserved elite footprints [87], together with unambiguous knowledge of dinosaur foot morphology, it is theoretically possible to confidently suggest possible print makers. That this should then be taken further and assigned a name to the footprint that connects it to its presumed maker is not a practice we would advocate. For example, prints originally described and named Iguanodonichnus frenkii and Neosauropus lagosteiriensis have been subsequently reinterpreted as being of sauropod and bipedal dinosaur origin, respectively [4,88-90].

However, there are some print types from the Cleveland Basin from which it is quite feasible to suggest their makers (at least to family level) with considerable confidence. Among these are the large prints (up to $1 \mathrm{~m}$ or more across) subspherical to oval in outline and with generally small, and sometimes curved up to five digit impressions. This group of prints, represented by Ai-Aiv in Group A (Figure 3) belong to sauropod makers, and the markedly different forms of these in the Cleveland Basin suggest that at least two and possibly three different sauropod types inhabited Yorkshire during the Middle Jurassic. Print type Ai (Brontopodus ichnosp., and Aii and Aiii (Breviparopus-like ichnosp.) (Figure 4) have been taken to indicate the presence of brachiosaur sauropods for the former [73,89], and a non-brachiosaurid [89] such as Cetiosaurus for the latter [77].

The final print in Group A (Figure 4, Av), Deltapodus brodricki, has had a more controversial history in terms of its likely maker. Originally, it was tentatively thought to have been made by a sauropod [60,61] but was subsequently reinterpreted as possibly having a stegosaur maker [62].

Apart from the above sauropod and stegosaur suggestions, it is extremely difficult to assign specific makers to individual print types. However, a provisional classification into 'Ornithopoda' or 'Theropoda' may be attempted for the print types in Group B. This was attempted by Whyte and others [77], where five 'ornithopods' (Bi, Biii, Biv, Bx, Bxvi) and four 'theropods' (Bii, Bv, Bxii, BBxviii) were recognized. In addition, eight further prints (Bvi-ix, Bxi, Bxiii-xv) were classified as 'small gracile' prints. The two slender gracile prints from the Cleveland Basin (Figure 4, Bxiv, Bxv) are particularly 
distinctive. Their wide divarication $\left(105^{\circ}\right.$ and $145^{\circ}$, respectively [18] is more reminiscent of birds, and indeed Currie [91] maintained that the 'divarification between digits II and IV in even the smallest dinosaurs never exceeds $100^{\circ}$ on an average per trackway'. This apparent anomaly suggests either that birds were around as early as the Middle Jurassic, or (more likely) that some small dinosaurs (small adults or juveniles) did indeed exhibit such large divarication in the digits of their pes. The two print types Bxiv and Bxv (Figure 4) resemble some traces assigned to Trisauropodiscus, but the Cleveland Basin specimens lack the hallux imprint and, in the case of Bxv, show a wider divarication of digits II and IV [92].

In the final group of morphotypes, Group C (Figure 4), it is normally not possible to suggest the dinosaur makers, since these prints are purely the result of a behavioural (swimming) pattern that does not necessarily reflect the morphology of the foot, except in the extreme case of recording the number of digits (or at least those that made contact with the substrate), the divarification of the digits and whether the digit ended in claws or rounded terminations. However, two examples from the Cleveland Basin have been published where a swimming trace has been connected to walking prints that reflect the shape of the maker's foot. One of these, the least certain, was described by Whyte and Romano [63] when describing a dinosaur ichnocoenosis that showed walking, running and swimming prints. In this work, they suggested that the animal that made a walking trackway (Trackway C) was also responsible for the swimming Trackway B (Figure 6 [18,63]), represented by $\mathrm{Ci}$ in Figure 4. The second example is of a swimming track made by the same (type of) animal that made associated tracks of Deltapodus brodricki. Since D. brodricki is considered to have been made by a stegosaur (see above [62]), the described swimming trackway (track Cii in Figure 4, and also Ciii) that showed a number of features that connected it to the walking tracks provided suggestive evidence that stegosaurs could swim [79].

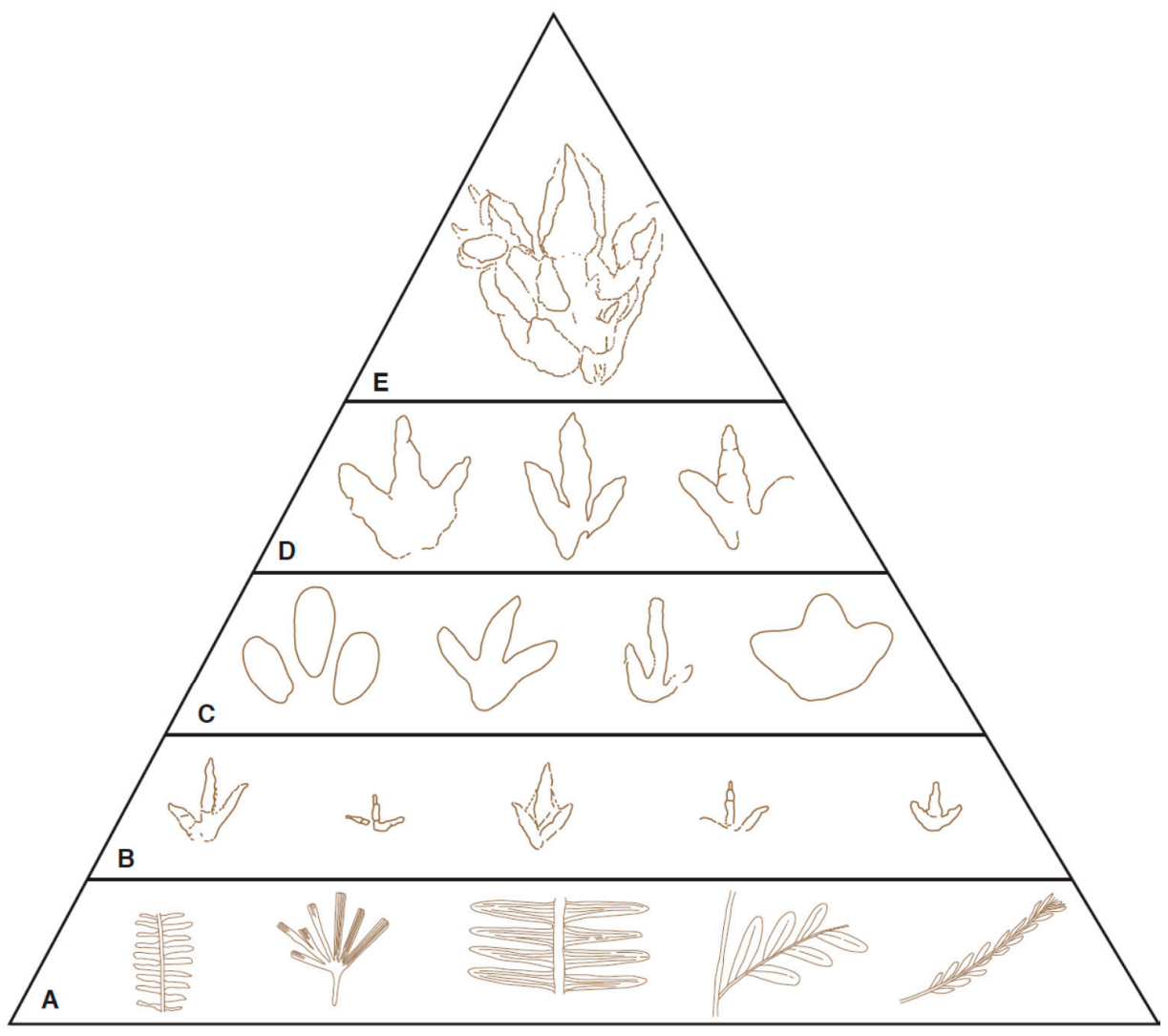

Figure 6. A schematic food chain diagram with drawings of representative tridactyl prints from the Cleveland and Hebrides basins. The prints are not drawn to the same scale. The examples of the plants at Level A are taken from specimens recorded from the Cleveland Basin. 
The small prints ( $<20 \mathrm{~cm}$ length) from the Valtos Sandstone and Kilmaluag formations of the Hebrides Basin have been provisionally assigned to small theropod dinosaurs. The larger footprints from the Valtos Sandstone Formation are interpreted as having been made by a large ornithopod (Table 1. PCA group Z), while the third group of large tridactyl tracks from the Duntulm Formation are regarded as large theropod tracks (Table 1. PCA group Y) [68,71,72]. The large track from the Valtos Sandstone Formation may be a large form of (Table 1. PCA group Y), but the preservation was not good enough to provide reliable data. The sauropod prints recently described from the Duntulm Formation were assigned to a non-neosauropod maker [39].

\section{Palaeobiogeographical Aspects of the Dinosaur Communities Based on both Body- and Ichno-Fossil Evidence}

It is proposed that similarities between the dinosaur ichnofaunas of the Cleveland and Hebrides basins may indicate that interchange of faunas took place between the two areas during the Jurassic. Whether this took place by chance or was the result of intentional migrations as a result of climatic pressures or searching for new food on during seasonal changes is not possible to speculate. However, certainly, the distances involved would not be excessive, since modern day wildebeest and zebra migrate over $3000 \mathrm{~km}$ each year in search of rain-ripened grass. Caribou migrate about $700 \mathrm{~km}$ from their wintering grounds to their calving grounds [93] and can accumulate up to more than $5000 \mathrm{~km}$ in a year [94] for the round journey.

From the diverse ichnofaunas of the Cleveland and Hebrides basins during the Middle Jurassic, it is apparent that both areas supported rich and varied dinosaur communities within this brief period of time (c. $10 \mathrm{Ma}$ for the Cleveland Basin, and less for the Hebrides Basin). The former has evidence of brachiosaur dinosaurs and non-brachiosaur 'Cetiosaurus-type' dinosaurs, from the Aalenian and Bathonian (and by inference from the Bajocian as well). These giant quadrupeds, which are represented by at least two and possibly three genera, invaded the Cleveland area during the earliest Middle Jurassic and were a dominant part of the community until persistent marine conditions returned in the Callovian. In the Hebrides Basin, sauropod remains are first recorded in the Valtos Sandstone Formation (Bathonian) where a footprint, (as well as bones and a tooth) have been found of a primitive eusauropod [45,47]. Further footprints and trackways of a primitive, non-neosauropod species have been found in the Duntulm Formation from the Trotternish Peninsula and represent the most northerly Middle Jurassic sauropod tracksite currently known [39]. The last occurrence of sauropod remains being from the Kilmaluag Formation in Strathaird, southern Skye where a peg-like tooth was found that could belong to either a basal eusauropod or a basal titanosauriform [48]. Sauropod prints have not yet been recorded from this unit. It is possible that these represent three different sauropod types on the Isle of Skye in the Middle Jurassic, and are thus comparable in diversity to that of the Cleveland Basin. Their presence first in the Cleveland Basin may suggest that they later spread to the Hebrides Basin. Whether this took place over the 'highland' of the Scottish and Pennine landmasses separating the two depocentres, or by way of the marginal alluvial plains and deltas (Figure 2) is not possible to say. Certainly, the 'highlands' do not appear to have been a major physical barrier, since the general lack of much coarse-grained sediment at least in the Cleveland Basin indicates a rather subdued topography (see Section 2). The abundance of plant remains [24], both as in situ erect stems (and rootlet beds) and isolated drifted leaves and trunks [5], indicates a rich source of plant food, both on the alluvial plain and in the hinterland [95]. Thus, migrations from the Cleveland to Hebrides area could have taken place either around the margins of the land masses or over their tops. It has been suggested that the long legs of sauropods aided long distance movement [1]. If this was the case, then the journey from the Cleveland Basin to the Hebrides Basin would appear to be quite achievable.

An apparent anomaly is the relatively common occurrence of possible stegosaur prints (Deltapodus) from the Cleveland Basin, and their apparent absence from the currently described track record of the Hebrides Basin. Deltapodus tracks are first recorded from the Aalenian of the Cleveland Basin, and subsequently occur in Upper Jurassic and Lower Cretaceous on a world-wide scale (see Section 5 
above). Whether they occur in the Hebrides Basin and have not yet been recognized, or if indeed they are not present in the latter is not possible to determine at this time. Despite the lack of footprints of stegosaurs from the Hebrides Basin, there is the proximal ulna and radius of a thyreophoran that may be an early stegosaur or ankylosaur [51] as well as other undescribed bones that may belong to this group also. However, it still remains difficult to account for the absence of Deltapodus tracks in the Hebrides Basin. In addition, even if such tracks are eventually identified, they may have been rare because they have yet to be found in the same sites where so many sauropod and tridactyl dinosaur (theropod and ornithopod) tracks have been found. Even if stegosaurs (the suggested Deltapodus maker) were not physically suited to making excursions inland, away from the more flat-lying alluvial plains, they presumably could have explored the routes around the margins of the landmasses which were probably nearly continuous from Mid-Late Bathonian times (Figure 2C,D). The presence of river systems along such routes should not have been an obstacle to stegosaur movement since it has been shown recently that stegosaurs were probably capable of swimming [79].

Among the tridactyl tracks, the largest theropod tracks (Bxviii) from the Cleveland Basin are rare, with only two described examples [76,77]. Slightly smaller tracks made by theropods are represented by morphotypes Bii, Bv and Bxii (Figure 4) [77]. Two size ranges of prints made by ornithopods have also been identified; those of medium size (Bi, Biii, Biv, Bx, Bxvi), and those of small $(<20 \mathrm{~cm})$ gracile prints (Bvi-viii, xi, xiii-xv, ix) [77]. In the Hebrides Basin, close comparisons may be made with some of the Cleveland Basin morphotypes (Table 1), and broadly similar groups are represented, although on the whole diversity is less. This suggests that the food chains in the two areas are comparable (see Section 9) and may have arisen from either the interchange of faunas from the two basins, or the (continuous or intermittent) influx of faunas from one basin to the other. In this scenario, we suggest that, since the Yorkshire Basin was established and colonized first, it was possible that initial migrations at first were from the Cleveland Basin to the Hebrides Basin.

While the above discussions are centered on the possibility of faunal exchange between the Cleveland and Hebrides basins during the Middle Jurassic, it cannot be discounted that animals also made their way into the Hebrides Basin from the 'west', from the landmass of Laurasia. In addition, of course, it still leaves unresolved the problem where the animals came from initially to colonise the slightly older Cleveland Basin. Most of the basins around Scotland at that time (until the Callovian) had shallow lagoonal and river deposits rather than open marine with deep channels, so it is equally possible that the dinosaurs came from North America across to the UK area via Greenland. The Bathonian dinosaur footprints from Wyoming are also indistinguishable from the footprints of the Kilmaluag Formation on Skye based on comparisons between landmark data [72]. Sediment appears to have been derived from a southeasterly source during the deposition of the Great Estuarine Group in the Hebrides Basin, although it seems mostly to have been locally derived from the Scottish mainland [96].

\section{Structure of the Middle Jurassic Terrestrial Dinosaur Ecosystems from the Cleveland and Hebrides Basins as Deduced from Their Prints-A Tentative Food Chain}

Finally, we attempt to portray visually the structure of the dinosaur ecosystems of the two basins during the Middle Jurassic. This is based on the print types and their relative abundance within the community. A visual representation has previously been attempted for part of a beach section within the Scalby Formation of the Cleveland Basin [77], where the abundances of three groups (large tridactyl, small tridactyl and sauropod) were based on the relative numbers of their prints. While we categorically accept that this approach is not based on a firm statistical basis, and is heavily dependent on collector's bias and exposure, we feel that a visual portrayal has some benefit in trying to reconstruct the past community based on our current level of understanding (and with the recognition that such visual portrayals can be easily modified with new discoveries). We here propose a broadly similar visual approach, based on the prints recorded within the sequences, except that the diagram is in the form of a food chain that shows how food energy moves from one organism to another (where one 
animal eats another animal that is lower in the food chain) in a given environment. At each level of the food chain, print examples are known from both the Cleveland and Hebrides basins.

The diagram (Figure 6) starts at the base of the food chain with a selected sample of the diverse flora that existed at the time. Over 250 plant species have been recorded from the Yorkshire Basin, representing species that lived on the alluvial plain or in the adjacent hinterland. These belong to conifers, ferns, bryophytes, lycopsids, sphenophytes, pteridosperms, Caytoniales, Cycadales, Ginkgoales and Bennettitales [24,95,97,98], while allochthonous floras have been recorded from Skye [99]. The next layer in the food chain may be represented by the small gracile forms, both herbivorous ornithischians (not illustrated in Figure 6) feeding on this flora and carnivorous theropods. The latter would be feeding on small prey that includes the diverse invertebrate fauna (not represented on the diagram) that was likely present at that time, such as arthropods, bivalves, annelids, as well as fish, pond tortoises [48], small ornithischians, and perhaps cadavers that were the result of natural death or the remains of a kill from the larger theropods. Medium to large size ornithischians (including ornithopods and stegosaurs) would occupy the next level of the food chain. This group of animals, probably existing in herds, would generally not be troubled by small carnivores, and could browse on the higher vegetation of leaves and young shoots not available to their smaller relatives. The final two layers in the food chain were the domain of the large carnivores. Whether these animals were primarily hunters, scavengers or both may remain open to question, but their position at the top of the food chain is without doubt. It is interesting to note that the largest theropod prints found are very rare. Only two clear examples are known from the Cleveland Basin, identified as morphotype Bxviii [76,77], and were tentatively assigned to a Megalosaurus maker [76]. In the Hebrides Basin, theropod tracks over $40 \mathrm{~cm}$ in length are known from the Duntulm Formation, and a recently found tridactyl print from the Valtos Sandstone Formation is over $1 \mathrm{~m}$ in length (although it is unclear if this was made by a theropod or an ornithopod). The scarcity of top predator, as evidenced by their meager print record, organisms at the top of the food chain is well shown in the dinosaur print record of the Cleveland Basin where the two prints of these large carnivores contrasts with nearly 40 of a small bipedal gracile form such as Bix [77].

The two remaining groups not incorporated into the food chain are those represented by the morphotypes in Group A (Figure 4); the sauropods (Ai-iv) and stegosaurs (Av). Sauropod food requirements of these giant herbivores 'must have been impressive' [84], but they presumably found sufficient food in the abundant and diverse plant life that colonized the levees of the river systems in the alluvial plains. The food chain of these animals is much reduced compared with that described above. Although it is likely that carnivores repeatedly hunted small sauropods, it is equally likely that their success was limited when confronted by the enormous body size of an adult sauropod [96]. Whether there was competition for food between the brachiosaur dinosaurs and non-brachiosaur 'Cetiosaurus-type' dinosaurs in the Cleveland Basin [5,65], or the eusauropods and Cetiosaurid in the Hebrides Basin $[39,45,47]$ is not possible to tell. However, from the print evidence of these giant animals in the Cleveland Basin, they coexisted from the Aalenian to Bathonian (Figure 5).

Whatever the actual food requirements were for these morphologically diverse Middle Jurassic herbivores, the range of plant food available both on the flood plains and in the hinterland was exceedingly diverse as can be deduced from studies of plant remains and spore-pollen assemblages $[24,95,97,98,100]$.

A similarly restricted food chain must have existed for the stegosaurs. As with the sauropods, stegosaurs were herbivorous animals [97], yet despite their considerable bulk, they were significantly smaller than the sauropods and did not possess an elongated neck nor long legs (particularly the anterior pair). Hence, they are generally considered to be low browsers [95,100], even if they were capable, as has been suggested, to rear up on their hind legs using the tail as a tripod to feed on leaves higher up in the trees [101]. Large theropods may have preyed on stegosaurs, but the rows of dorsal plates and the spiny termination to their tail may have proved an effective deterrent. 


\section{Problems still to Be Resolved}

Despite our knowledge of the dinosaur tracks and their probable makers within the Cleveland and Hebrides basins, there are still many outstanding problems to be resolved. We have virtually no evidence of social behaviour, such as herding and post-hatching care, from the footprints, but this is almost certainly the result of the lack of large bedding planes in the mainly coastal exposures. We also lack any evidence of eggs and nesting sites from either of the two basins., and only a single recording of tridactyl tracks of small/juvenile bipedal forms from the Cleveland Basin for one of the morphotypes (Figure 4, Bix) [77]. There are, however, juvenile and hatchling tracks in the Hebrides Basin in the Kilmaluag Formation [40,72] and also size variations in the footprints in the Valtos Sandstone Formation $[69,71,72]$. The footprints on a single slab of the Kilmaluag Formation with the two track sizes may indicate that there was post-hatching care in theropods as all the tracks are pointing in the same direction [40]. The slab, however, only shows about 24 footprints within the $100 \mathrm{~cm} \times 175 \mathrm{~cm}$ area. The only non-sauropod quadruped maker for which juvenile prints have been recorded are for morphotype Av (Figure 4) [77] from the Cleveland Basin. Until now, no small/juvenile tracks have been recorded for sauropods from either the Cleveland area (Figure 4, morphotypes Ai-Aiv) or Isle of Skye. It is tempting to explain the absence of the latter by proposing that nests were made in the drier upland areas adjacent to the two basins, and so that is where small (baby and juvenile) dinosaur tracks would have been made, before making their way as young adults to the coastal and alluvial plains. However, it is also relevant to appreciate that the general absence of very small tracks is not a preservational phenomenon, since delicate tracks made by small non-dinosaurian vertebrates and invertebrates are common in the fine-grained sedimentary rocks of the two basins [8,70]. More work is needed on these two classic areas before we can begin to unravel the full story.

Author Contributions: M.R. was the primary author and contributed the information relating to the Cleveland Basin. N.D.L.C. and S.L.B. contributed the information relating to the Hebrides Basin.

Funding: The authors also thank the National Geographic Society for funding the PalAlba fieldwork (grant GEFNE185-16) to the Hebrides Basin.

Acknowledgments: The authors would like to thank the four anonymous reviewers for their useful and constructive comments. We wish to thank Paul Coles for redrawing the figures. The PalAlba research group is thanked for its continuing to add further information to the Middle Jurassic dinosaur fauna of the Hebrides Basin with a special thank you to Paige dePolo, Tom Challands, Davide Foffa, Mark Wilkinson, and Dugald Ross for their collaboration to the study of Scottish dinosaur tracks.

Conflicts of Interest: The authors declare no conflict of interest.

\section{References}

1. Weishampel, D.B. Dinosaurian Distribution. In The Dinosauria; Weishampel, D.B., Dodson, P., Osmolska, H., Eds.; University of California Press: Oakland, CA, USA, 1990; pp. 63-139.

2. Benton, M.J. Reptilia. In The Fossil Record 2; Benton, M.J., Ed.; Chapman \& Hall: London, UK, 1993; pp. 681-715.

3. Benton, M.J. The Penguin Historical Atlas of the Dinosaurs; Penguin Group: London, UK, 1996; 144p.

4. Lockley, M.G.; Farlow, J.O.; Meyer, C.A. Brontopodus and Parabrontopodus ichnogen. nov. and the significance of wide- and narrow-gauge sauropod trackways. Gaia 1994, 10, 135-145.

5. Romano, M.; Whyte, M.A. Jurassic dinosaur tracks and trackways of the Cleveland Basin, Yorkshire: Preservation, diversity and distribution. Proc. Yorks. Geol. Soc. 2003, 54, 185-215. [CrossRef]

6. Prince, N.K.; Lockley, M.G. The sedimentology of the Purgatoire tracksite region, Morrison Formation of southeastern Colorado. In Dinosaur Tracks and Traces; Gillette, D.D., Lockley, M.G., Eds.; Cambridge Univ. Press: Cambridge, UK, 1989; pp. 155-163.

7. Santos, V.F.; Lockley, M.G.; Meyer, C.A.; Carvalho, J.; Galopim de Carvalho, A.M.; Moratalla, J.J. A new sauropod tracksite from the Middle Jurassic of Portugal. Gaia 1994, 10, 5-13.

8. Lockley, M.; Meyer, C. Dinosaur Tracks and Other Fossil Footprints of Europe; Columbia University Press: New York, NY, USA, 2000; 342p. 
9. Marty, D. Sedimentology, taphonomy, and ichnology of late Jurassic dinosaur tracks from the Jura carbonate platform (Chevenez-Combe Ronde tracksite, NW Switzerland): Insights into the tidal-flat palaeoenvironment and dinosaur diversity, locomotion, and palaeoecology. GeoFocus 2008, 21, 1-278.

10. Emeleus, C.H.; Bell, B.R. British Regional Geology: The Palaeogene Volcanic Districts of Scotland, 4th ed.; British Geological Survey: Nottingham, UK, 2005; 244p.

11. Morton, N. The Bearreraig Sandstone Series (Middle Jurassic) of Skye and Raasay. Scott. J. Geol. 1965, 1, 189-216. [CrossRef]

12. Hesselbo, S.P.; Oates, M.J.; Jenkyns, H.C. The lower Lias Group of the Hebrides Basin. Scott. J. Geol. 1998, 34, 23-60. [CrossRef]

13. Hesselbo, S.P.; Coe, A.C. Jurassic sequences in the Hebridean Basin, Isle of Skye, Scotland. In Field Guide Book, International Association of Sedimentologists Meeting, Dublin 2000; Graham, J.R., Ryan, A., Eds.; University of Dublin: Dublin, Eire, 2000; pp. 41-58.

14. Bradshaw, M.J.; Cope, J.C.W.; Cripps, D.W.; Donovan, D.T.; Howarth, M.K.; Rawson, P.F.; West, I.M.; Wimbledon, W.A. Jurassic. In Atlas of Palaeogegraphy and Lithofacies; Cope, J.C.W., Ingham, J.K., Rawson, P.F., Eds.; The Geological Society: London, UK, 1992; Volume 13, pp. 107-129.

15. Johnstone, G.S.; Mykura, W. British Regional Geology: The Northern Highlands of Scotland, 4th ed.; British Geological Survey: Nottingham, UK, 1989; 219p.

16. Andrews, J.E. The sedimentary facies of a late Bathonian regressive episode: The Kilmaluag and Skudiburgh formations of the Great Estuarine Group, Inner Hebrides, Scotland. J. Geol. Soc. 1985, 142, 1119-1137. [CrossRef]

17. Jackson, S.J.; Whyte, M.A.; Romano, M. Range of experimental dinosaur (Hypsilophodon foxii) footprints due to variation in sand consistency: How wet was the track? Ichnos 2010, 17, 197-214. [CrossRef]

18. Whyte, M.A.; Romano, M. A Dinosaur ichnocoenosis from the Middle Jurassic of Yorkshire, UK. Ichnos 2001, 8, 223-234. [CrossRef]

19. Alexander, J. Deltaic or coastal plain? With an example of the controversy from the Middle Jurassic of Yorkshire. In Deltas: Sites and Traps for Fossil Fuels; Whateley, M.K.G., Pickering, K.T., Eds.; Geological Society: London, UK, 1989; Volume 41, pp. 11-19.

20. Hemingway, J.E. Jurassic. In The Geology and Mineral Resources of Yorkshire; Rayner, D.H., Hemingway, J.E., Eds.; Yorkshire Geological Society Occasional Publication: Dorset, UK, 1974; Volume 2, pp. 161-223.

21. Powell, J.H. Jurassic sedimentation in the Cleveland Basin: A review. Proc. Yorks. Geol. Soc. 2010, 58, $21-72$. [CrossRef]

22. Eschard, R.; Ravenne, C.; Houel, P.; Knox, R. Three-dimensional reservoir architecture of a valley-fill sequence and a deltaic aggradational sequence: Influences of minor relative sea-level changes. In The Three-Dimensional Facies Architecture of Terrigenous Clastic Sediments and Its Implications for Hydrocarbon Discovery and Recovery; Concepts in Sedimentology; Miall, A.D., Tyler, N., Eds.; SEPM: Tulsa, OK, USA, 1991; Volume 3, pp. $133-147$.

23. Rawson, P.F.; Wright, J.K. The Yorkshire Coast. Geologists' Association Guide, 34; Geologists' Association: London, UK, 2000; 47p.

24. Konijnenburg-Van Cittert, J.H.A.; Morgans, H.S. The Jurassic Flora of Yorkshire. Field Guide to Fossils, 8; The Palaeontological Association: London, UK, 1999; 134p.

25. Black, M. Drifted plant beds of the Upper Estuarine Series of Yorkshire. Q. J. Geol. Soc. 1929, 85, 389-437. [CrossRef]

26. Goldring, R.; Pollard, J.E. A re-evaluation of Ophiomorpha burrows in the Wealden (lower Cretaceous) of southern England. Cretac. Res. 1995, 16, 665-680. [CrossRef]

27. Romano, M.; Whyte, M.A. A limulid trace fossil from the Scarborough Formation (Jurassic) of Yorkshire; its occurrence, taxonomy and interpretation. Proc. Yorks. Geol. Soc. 1987, 47, 85-95. [CrossRef]

28. Romano, M.; Whyte, M.A. Selenichnites, a new name for the ichnogenus Selenichnus. Proc. Yorks. Geol. Soc. 1990, 48, 221. [CrossRef]

29. Romano, M.; Whyte, M.A. A new record of the trace fossil Selenichnites from the Middle Jurassic Scalby Formation of the Cleveland Basin, Yorkshire. Proc. Yorks. Geol. Soc. 2013, 59, 203-210. [CrossRef]

30. Romano, M.; Whyte, M.A. A review of the trace fossil Selenichnites. Proc. Yorks. Geol. Soc. 2015, 60, $275-288$. [CrossRef]

31. Romano, M.; Whyte, M.A. The first record of xiphosurid (arthropod) trackways from the Saltwick Formation, Middle Jurassic of the Cleveland Basin, Yorkshire. Palaeontology 2003, 46, 257-269. [CrossRef] 
32. Romano, M.; Taylor, R. Notes on new xiphosurid (horseshoe crab) trackways from the Middle Jurassic of the Cleveland Basin, Yorkshire. Proc. Yorks. Geol. Soc. 2016, 61, 155-160. [CrossRef]

33. Knox, R.W.; Howard, A.S.; Powell, J.H.; Van Buchem, F.S.P. Lower and Middle Jurassic Sediments of the Cleveland Basin, N. E. England: Shallow Marine and Paralic Fades Seen in Their Sequence Stratigraphic Context. Field Guide, 5. In Proceedings of the Sediments 1990: 13th International Sedimentological Congress, Nottingham, UK, 26-31 August 1990.

34. Korte, C.; Hesselbo, S.P.; Ullmann, C.V.; Dietl, G.; Ruhl, M.; Schweigert, G.; Thibault, N. Jurassic climate mode governed by ocean gateway. Nat. Commun. 2015, 6, 10015. [CrossRef] [PubMed]

35. Hudson, J.D.; Clements, R.G.; Riding, J.B.; Wakefield, M.I.; Walton, W. Jurassic Paleosalinities and Brackish-water Communities-A Case Study. Palaios 1995, 10, 392-407. [CrossRef]

36. Harris, J.P. Mid-Jurassic delta systems in the Hebridean basins: Thickness and facies distribution patterns of potential reservoir sandbodies. In Basins on the Atlantic Seaboard: Petroleum Geology, Sedimentology and Basin Evolution; Parnell, J., Ed.; Special Publication of the Geological Society: London, UK, 1992; Volume 62, pp. 111-144.

37. Price, G.D.; Teece, C. Reconstruction of Jurassic (Bathonian) palaeosalinity using stable isotopes and faunal associations. J. Geol. Soc. 2010, 167, 1199-1208. [CrossRef]

38. Andrews, J.E.; Walton, W. Depositional environments within Middle Jurassic oyster-dominated lagoons: An integrated litho- bio- and palynofacies study of the Duntulm Formation (Great Estuarine Group, Inner Hebrides). Trans. R. Soc. Edinb. 1990, 81, 1-22. [CrossRef]

39. Brusatte, S.L.; Challands, T.J.; Ross, D.A.; Wilkinson, M. Sauropod dinosaur trackways in a Middle Jurassic lagoon on the Isle of Skye, Scotland. Scott. J. Geol. 2015, 52, 1-9. [CrossRef]

40. Clark, N.D.L.; Ross, D.A.; Booth, P. Dinosaur tracks from the Kilmaluag Formation (Bathonian, Middle Jurassic) of Score Bay, Isle of Skye, Scotland, UK. Ichnos 2005, 12, 93-104. [CrossRef]

41. Williamson, W.C. On the distribution of fossil remains on the Yorkshire Coast, from the Lower Lias to the Bath Oolite. Trans. Geol. Soc. Lond. 1837, 5, 223-242. [CrossRef]

42. Whyte, M.A.; Romano, M.; Watts, W. Yorkshire dinosaurs: A history in two parts. In Dinosaurs and Other Extinct Saurians: A Historical Perspective; Moody, R.T.J., Buffetaut, E., Naish, D., Martill, D.M., Eds.; Geological Society: London, UK, 2010; Volume 343, pp. 189-207.

43. Manning, P.L.; Egerton, V.M.; Romano, M. A New Sauropod Dinosaur from the Middle Jurassic of the United Kingdom. PLoS ONE 2015, 10, 7. [CrossRef] [PubMed]

44. Clark, N.D.L. Review of the dinosaur remains from the Middle Jurassic of Scotland, UK. Geosciences $2018,8$. [CrossRef]

45. Clark, N.D.L.; Boyd, J.D.; Dixon, R.J.; Ross, D.A. The first Middle Jurassic dinosaur from Scotland: A cetiosaurid? (Sauropoda) from the Bathonian of the Isle of Skye. Scott. J. Geol. 1995, 31, 171-176. [CrossRef]

46. Liston, J.J. A re-examination of a Middle Jurassic sauropod limb bone from the Bathonian of the Isle of Skye. Scott. J. Geol. 2004, 40, 119-122. [CrossRef]

47. Clark, N.D.L.; Gavin, P. New Bathonian (Middle Jurassic) sauropod remains from the Valtos Formation, Isle of Skye, Scotland. Scott. J. Geol. 2016, 52, 71-75. [CrossRef]

48. Barrett, P.M. A sauropod dinosaur tooth from the Middle Jurassic of Skye, Scotland. Trans. R. Soc. Edinb. Earth Sci. 2006, 97, 25-29. [CrossRef]

49. Brusatte, S.L.; Clark, N.D.L. Theropod dinosaurs from the Middle Jurassic (Bajocian-Bathonian) of Skye, Scotland. Scott. J. Geol. 2015, 51, 157-164. [CrossRef]

50. Rees, J.; Underwood, C.J. Hybodont sharks from the Middle Jurassic of the Inner Hebrides, Scotland. Trans. R. Soc. Edinb. Earth Sci. 2006, 96, 351-363. [CrossRef]

51. Clark, N.D.L. A thyreophoran dinosaur from the early Bajocian (Middle Jurassic) of the Isle of Skye, Scotland. Scott. J. Geol. 2001, 37, 19-26. [CrossRef]

52. Hargreaves, J.A. Fossil footprints near Scarborough. Naturalist 1913, 673, 92-95.

53. Brodrick, H. A find!!! Rep. Whitby Philos. Soc. 1907, 85, 8-9.

54. Brodrick, H. Note on further footprint casts found in the Inferior Oolite at Saltwick. Rep. Whitby Philos. Soc. 1908, 86, 6-7.

55. Brodrick, H. Note on Casts of Dinosaurian Footprints in the Lower Oolite at Whitby. In Report of the British Association for the Advancement of Science (Dublin 1908); John Murray: London, UK, 1909; pp. 707-708. 
56. Brodrick, H. Note on Footprint casts from the Inferior Oolite near Whitby, Yorkshire. Proc. Liverp. Geol. Soc. $1909,10,327-335$.

57. Hargreaves, J.A. Fossil footprints near Scarborough. Naturalist 1914, 688, 154-156.

58. Sarjeant, W.A.S. Fossil footprints from the middle Triassic of Nottinghamshire and the middle Jurassic of Yorkshire. Mercian Geol. 1970, 3, 269-282.

59. Ivens, C.R.; Watson, G.G. Records of Dinosaur Footprints on the Northeast Yorkshire Coast 1895-1993; Roseberry Publications: Middlesborough, UK, 1994; 20p.

60. Whyte, M.A.; Romano, M. Footprints of a sauropod dinosaur from the Middle Jurassic of Yorkshire. Proc. Geol. Assoc. 1993, 104, 195-199. [CrossRef]

61. Whyte, M.A.; Romano, M. Probable sauropod prints from the Middle Jurassic of Yorkshire England. Gaia $1995,10,15-26$.

62. Whyte, M.A.; Romano, M. Probable stegosaurian dinosaurian tracks from the Saltwick Formation (Middle Jurassic) of Yorkshire, England. Proc. Geol. Assoc. 2001, 112, 45-54. [CrossRef]

63. Whyte, M.A.; Romano, M. Dinosaur footprints associated with an ephemeral pool in the Middle Jurassic of Yorkshire. Oryctos 2008, 8, 15-27.

64. Romano, M.; Whyte, M.A. Information on the foot morphology, pedal skin texture and limb dynamics of sauropods: Evidence from the ichnological record of the Middle Jurassic of the Cleveland Basin, Yorkshire, UK. Zubía 2012, 30, 45-92.

65. Romano, M.; Whyte, M.A.; Manning, P.L. New sauropod dinosaur prints from the Saltwick Formation (Middle Jurassic) of the Cleveland Basin, Yorkshire. Proc. Yorks. Geol. Soc. 1999, 52, 361-369. [CrossRef]

66. Romano, M.; Whyte, M.A.; Jackson, S.J. Trackway Ratio: A new look at trackway gauge in the analysis of quadrupedal dinosaur trackways and its implication for taxonomy. Ichnos 2007, 14, 257-270. [CrossRef]

67. Hudson, J.D. The Great Estuarine group (Jurassic, Scotland) as a source of vertebrate fossils: Some reminiscences and field trips. Palaeontol. Assoc. Newslett. 2016, 92, 61-66.

68. Andrews, J.E.; Hudson, J.D. First Jurassic dinosaur footprint from Scotland. Scott. J. Geol. 1984, $20,129-134$. [CrossRef]

69. Clark, N.D.L.; Barco Rodríguez, J.I. The first dinosaur trackway from the Valtos Sandstone Formation (Bathonian, Jurassic) of the Isle of Skye, Scotland. Geogaceta 1998, 24, 79-82.

70. Clark, N.D.L.; Booth, P.; Booth, C.; Ross, D.A. Dinosaur footprints from the Duntulm Formation (Bathonian, Jurassic) of the Isle of Skye. Scott. J. Geol. 2004, 40, 13-21. [CrossRef]

71. Marshall, P. Theropod dinosaur and other footprints from the Valtos Sandstone Formation (Bathonian, Middle Jurassic) of the Isle of Skye. Scott. J. Geol. 2005, 41, 97-104. [CrossRef]

72. Clark, N.D.L.; Brett-Surman, M.K. A comparison between dinosaur footprints from the Middle Jurassic of the Isle of Skye, Scotland, UK, and Shell, Wyoming, USA. Scott. J. Geol. 2008, 44, 139-150. [CrossRef]

73. Farlow, J.O.; Pittman, J.G.; Hawthorne, J.M. Brontopodus birdi, Lower Cretaceous Sauropod Footprints from the U.S. Gulf Coastal Plain. In Dinosaur Tracks and Traces; Gillette, D.D., Lockley, M.G., Eds.; Cambridge University Press: Cambridge, UK, 1989; pp. 371-394.

74. Mateus, O.; Milan, J. A diverse Upper Jurassic dinosaur ichnofauna from central-west Portugal. Lethaia 2009, 43, 245-257. Available online: http:/ / onlinelibrary.wiley.com/doi/10.1111/j.1502-3931.2009.00190.x/epdf (accessed on 15 February 2017). [CrossRef]

75. Xing, L.; Lockley, M.G.; McCrea, R.T.; Gierliński, G.D.; Buckley, L.G.; Zhang, J.; Qi, L.; Chengkai, J. First record of Deltapodus tracks from the Early Cretaceous of China. Cretac. Res. 2013, 42, 55-65. [CrossRef]

76. Whyte, M.A.; Romano, M.; Hudson, J.G.; Watts, W. Discovery of the largest theropod dinosaur track known from the Middle Jurassic of Yorkshire. Proc. Yorks. Geol. Soc. 2006, 56, 77-80. [CrossRef]

77. Whyte, M.A.; Romano, M.; Elvidge, D.J. Reconstruction of Middle Jurassic Dinosaur-Dominated Communities from the Vertebrate Ichnofauna of the Cleveland Basin of Yorkshire, UK. Ichnos 2007, 14, 117-129. [CrossRef]

78. Black, M.; Hemingway, J.E.; Wilson, V. Summer field meeting to north-east Yorkshire: August 9th to 20th, 1934. Proc. Geol. Assoc. 1934, 54, 291-306. [CrossRef]

79. Romano, M.; Whyte, M.A. Could stegosaurs swim? Suggestive evidence from the Middle Jurassic tracksite of the Cleveland Basin, Yorkshire. Proc. Yorks. Geol. Soc. 2015, 60, 227-233. [CrossRef]

80. Thulborn, T. Dinosaur Tracks; Chapman \& Hall: London, UK, 1990; 424p. 
81. Lockley, M.G.; Meyer, C.A.; Hunt, A. The distribution of sauropod tracks and trackmakers. In Aspects of Sauropod Paleobiology, Gaia No. 10; Lockley, M.G., dos Santos, V.F., Meyer, C.A., Hunt, A., Eds.; University of Lisbon: Lisbon, Portugal, 1994; pp. 233-248.

82. Falkingham, P.L.; Marty, D.; Richter, A. Introduction. In Dinosaur Tracks: The Next Steps (Life of the Past); Falkingham, P.L., Marty, D., Richter, A., Eds.; Indiana Press: Bloomington, IN, USA, 2016; pp. 3-11.

83. Lomax, D.R.; Racay, C.A.; Long, A. Mortichnial Trackway of Mesolimulus walchi from the Upper Jurassic Solnhofen Lithographic Limestone near Wintershof, Germany. Ichnos 2012, 19, 175-183. [CrossRef]

84. Donovan, S.K. Cruziana and Rusophycus: Trace fossils produced by trilobites ... in some cases? Lethaia 2010, 43, 283-284. [CrossRef]

85. Radley, J.D.; Barker, M.J.; Munt, M.C. Bivalve trace fossils (Lockeia) from the Barnes High Sandstone (Wealden Group, Lower Cretaceous) of the Wessex Sub-basin, southern England. Cretac. Res. 1998, 19, 505-509. [CrossRef]

86. Niedźwiedzki, G.; Singer, T.; Gierlinski, G.D.; Lockley, M.J. A protoceratopsid skeleton with an associated track from the Upper Cretaceous of Mongolia. Cretac. Res. 2012, 33, 7-10. [CrossRef]

87. Lockley, M.; Hunt, A.P. Dinosaur Tracks and Other Fossil Footprints of the Western United States; Columbia University Press: New York, NY, USA, 1995; 360p.

88. Santos, V.F.; Lockley, M.G.; Moratalla, J.J.; Galopim de Carvalho, A.M. The longest dinosaur trackway in the world? Interpretations of Cretaceous footprints from Carenque, near Lisbon, Portugal. Gaia 1992, 5, $18-27$.

89. Farlow, J.O. Sauropod tracks and trackmakers: Integrating the ichnological and sedimentological records. Zubía 1992, 10, 89-138.

90. Moreno, K.; Benton, M.J. Occurrence of sauropod dinosaur tracks in the Upper Jurassic of Chile (redescription of Iguanodonichnus frenki). J. S. Am. Earth Sci. 2005, 20, 253-257. [CrossRef]

91. Currie, P.J. Bird footprints from the Gething Formation (Aptian, Lower Cretaceous) of northeastern British Columbia, Canada. J. Vertebr. Paleontol. 1981, 1, 257-264. [CrossRef]

92. Gierliński, G.D.; Lagnaoui, A.; Klein, H.; Saber, H.; Oukassou, M.; Charrière, A. Bird-like tracks from the Imilchil Formation (Middle Jurassic, Bajocian-Bathonian) of the Central High Atlas, Morocco, in comparison with similar Mesozoic tridactylous ichnotaxa. Boll. Della Soc. Paleontol. Italiana 2017, 56, 207-215.

93. Zalatan, R.; Gunn, A.; Henry, G. Long-term abundance patterns of barren-ground caribou using trampling scars on roots of Picea Mariana in the Northwest Territories, Canada. Arct. Antarct. Alp. Res. 2006, 38, 624-630. [CrossRef]

94. Fancy, S.G.; Pank, L.F.; Whiten, K.R.; Regelin, W.L. Seasonal movement of caribou in arctic Alaska as determined by satellite. Can. J. Zool. 1989, 67, 644-650. [CrossRef]

95. Slater, S.M.; Wellman, C.H.; Romano, M.; Vajda, V. Dinosaur-plant interactions within a Middle Jurassic ecosystem-Palynology of the Burniston Bay dinosaur footprint locality, Yorkshire, UK. Palaeobiodivers. Palaeoenviron. 2018, 98, 139-151. [CrossRef]

96. Hudson, J.D. The petrology of the sandstones of the Great Estuarine Series and the Jurassic Palaeogeography of Scotland. Proc. Geol. Assoc. 1964, 75, 499-527. [CrossRef]

97. Slater, S.M.; Wellman, C.H. A quantitative comparison of dispersed spore/pollen and plant megafossil assemblages from a Middle Jurassic plant bed from Yorkshire, UK. Paleobiology 2015, 41, 640-660. [CrossRef]

98. Slater, S.M.; Wellman, C.H. Middle Jurassic vegetation dynamics based on quantitative analysis of spore/pollen assemblages from the Ravenscar Group, North Yorkshire, UK. Palaeontology 2016, 59, 305-328. [CrossRef]

99. Dodson, P. Sauropod Paleoecology. In The Dinosauria; Weishampel, D.B., Dodson, P., Osmolska, H., Eds.; University of California Press: Oakland, CA, USA, 1990; pp. 402-407.

100. Galton, P. Stegosauria. In The Dinosauria; Weishampel, D.B., Dodson, P., Osmolska, H., Eds.; University of California Press: Oakland, CA, USA, 1990; pp. 435-455.

101. Dower, B.L.; Bateman, R.M.; Stevenson, D.W. Systematics, ontogeny, and phylogenetic implications of exceptionally anatomically preserved Cycadophyte leaves from the Middle Jurassic of Bearreraig Bay, Skye, northwest Scotland. Bot. Rev. 2004, 70, 105-120. [CrossRef] 